ESTUDIOS 

REVISTA DE DERECHO UNED, NÚM. 8, 2011

\title{
LA CIUDADANÍA ANTE LA GLOBALIZACIÓN: NUEVOS MODELOS DE LA CIUDADANÍA POSTNACIONAL Y TRANSCULTURAL
}

\author{
Rafael Enrique Aguilera Portales*
}

Resumen: La actual crisis de la ciudadanía a nivel internacional esconde la actual crisis y reformulación del Estado-nación. En la actualidad, los conceptos de ciudadanía «ciudadanía mundial» o cosmopolitismo están sufriendo una fuerte revitalización debido a los fuertes cambios, transformaciones y tendencias emprendidos por la globalización a escala mundial. En este aspecto, un sector amplio de representantes del eurofederalismo defienden una posición cosmopolita al considerar que un Estado federal europeo puede ser el punto de partida para el establecimiento de un futuro régimen «político mundial» basado en tratados y organizaciones internacionales. El artículo trata de analizar distintos modelos de ciudadanía cosmopolita que presenta la Teoría Política contemporánea.

Palabras clave: ciudadanía, globalización, cosmopolitismo, Estadonación, eurofederalismo.

Abstract: The current crisis of citizenship hides the current international crisis and reformulation of the nation-state. Currently, the concepts of citizenship "world citizenship» and cosmopolitanism are experiencing a strong revival for strong changes, transformations and tendencies started by globalization worldwide. In this regard, a broad section of representatives of the euro-federalism defends the

\footnotetext{
" Profesor y coordinador del Departamento de Filosofía del Derecho del Centro de Investigaciones Jurídicas y Criminológicas de la Universidad Autónoma de Nuevo León (UANL), Monterrey.
} 
cosmopolitan position considering a European federal state as the starting point for the establishment of a future regime or "global policy» based on international treaties and organizations. The article tries with various models of cosmopolitan citizenship presented by contemporary political theory.

Key words: citizenship, globalization, cosmopolitanism, nation-state, euro-federalism.

Sumario: I. Nuevos retos de la globalización: hacia una ciudadanía cosmopolita.- II. Ciudadanía cívica y democrática en el Estado constitucional.- III. Distintos enfoques y modelos de ciudadanía cosmopolita.- III. 1. Modelo de patriotismo constitucional de Jürgen Habermas.- III. 2. Modelo de ciudadanía universal de Luigi Ferrajoli.III. 3. Modelo de ciudadanía constitucional mundial de Peter Häberle.- III. 4. Modelo de ciudadanía cosmopolita de David Held.III. 5. Modelo de ciudadanía cosmopolita de Martha Nussbaum.IV. El futuro de la ciudadanía cosmopolita ante la crisis del EstadoNación.

\section{NUEVOS RETOS DE LA GLOBALIZACIÓN: HACIA UNA CIUDADANÍA COSMOPOLITA}

La ciudadanía ha dejado de ser vista desde la concepción tradicional que otorgaba el Estado-nación para ser concebida de forma distinta y diferente por lo que su estatuto se encuentra mucho más confuso, indeterminado y borroso por los cambios políticos trascendentes que estamos viviendo. La ciudadanía aparece fragmentada bajo el horizonte de la globalización y sus contornos comienzan a agrietarse y confundirse. La actual crisis de la ciudadanía a nivel internacional esconde la actual crisis y reformulación del Estado-nación como modelo de organización jurídico-política hegemónica en los dos últimos siglos de historia, que comienza a extenderse hacia la grave crisis de los derechos humanos, del modelo democrático y del Estado Constitucional.

La mundialización del mercado económico junto a los nuevos fenómenos migratorios, la irrupción de las nuevas tecnologías, la industria mundial y la mejora de los transportes están provocando la generación de una cultura mundial poderosa y dominante. En este sentido, muchos pensadores prefieren hablar de globalización como sinónimo de occidentalización o americanización, pues advierten que el proceso de globalización no ha sido un fenómeno uniforme ni homogéneo. Por tanto, podemos advertir que los procesos de globa- 
lización ${ }^{1}$ no son sólo de naturaleza económica también son de naturaleza política y cultural. En la actualidad, la globalización nos remite a un cambio o transformación a escala mundial que enlaza comunidades distantes y expande el alcance de relaciones de poder a través de todas las regiones del mundo. La conciencia de interconexión creciente y mayor puede alimentar alianzas estratégicas y relaciones geopolíticas; pero también enemistades y xenofobias profundas entre distintos países. Estos procesos a menudo nos advierten lo limitado, pequeño y contingente de nuestros escenarios locales; igualmente nos presentan los riesgos, desafíos e incertidumbres a los que se encuentran ligados nuestros destinos colectivos como sociedades y comunidades. Mientras la revolución digital ha originado que nuestras comunicaciones se hagan cada vez más rápidas y veloces; se reducen las distancias espaciales, geográficas y temporales. El tradicional Estado moderno ya no se concibe como algo indivisible, único y soberano, sino como algo compartido con agencias internacionales; si los Estados ya no tienen pleno control sobre sus propios territorios, y si las fronteras territoriales y políticas son cada vez más difusas y permeables, los principios fundamentales con los que tradicionalmente ha operado la teoría política y jurídica como la democracia liberal, el consenso, la representación, el autogobierno, el demos y la soberanía se vuelven problemáticos y cuestionables y, sin duda, deben ser replanteados nuevamente.

La ciudadanía del mundo apenas se está esbozando, pensando, imaginando. Las integraciones supranacionales y supraestatales de la Unión Europea ponen de manifiesto nuevos modelos de ciudadanía nunca vistos anteriormente. La globalización económica ha alcanzado antes al ciudadano que la globalización jurídica de los derechos humanos o el proyecto humanista universal de una ciudadanía federal y cosmopolita planteado por el movimiento político ilustrado. Las estructuras que rigen el gobierno global y regional

${ }^{1}$ Puede consultarse una amplia bibliografía sobre esta problemática. Vid. IANNI, Octavio, La sociedad global, siglo XXI, México, $3^{\circ}$ edición, 1995; NorberT, Elías, La sociedad de los individuos, (trad. Cast. José Antonio Alemany), Barcelona, Ediciones Península, 1990; MARTINELLO, M., »Inmigración y construcción europea: ¿Hacia una ciudadanía multicultural en la Unión Europea?», trad. de M. Unceta, en Lamo de Espinosa, E. (ed.), Culturas, Estados, Ciudadanos, Alianza, Madrid, 1995; FARIÑAS, M. J., Globalización, ciudadanía y derechos humanos, Cuadernos Bartolomé de las Casas, Dykinson, Madrid, 2000; Thiebaut, C., «Cosmopolitismo y pertenencia», Laguna, número extraordinario, 1999, pp. 101-119; SANz BuRGos, Raúl, «¿Ofrecen las transformaciones globales oportunidades a la democratización?» en AGUILERA PORTALES, Rafael Enrique (coord.), La democracia en el Estado Constitucional, México, Porrúa, 2009. 
se encuentran en ubicadas en la Unión Europea (EU), el Área de Libre Comercio de América del Norte, el Fondo Monetario Internacional (FMI), el Banco Mundial (BM), Banco Internacional de Reconstrucción y Desarrollo (BIRD), la organización mundial de Comercio (OMC), G-8, Bank for Internacional Settlements (BIC) y el Acuerdo General de Aranceles y Comercio (GATT), así como las empresas transnacionales y las agencias multilaterales son los impulsores y garantes de un proceso veloz y rápido de globalización económica y política. La lógica de estos organismos internacionales ${ }^{2}$ se rige por criterios económicos y de mercado, donde priman las contribuciones al comercio, la inversión, la eficiencia de la producción, donde se cuestionan la relevancia de los Estados soberanos, especialmente en cuanto a sus actividades de protección social y local de ayuda a los más débiles y desamparados. En realidad, con estas gobernanza global ${ }^{3}$ ponemos de manifiesto que la prioridad se concede a la expansión y reproducción de los mercados globales. En esta línea, la gobernanza global es una gobernanza esencialmente neoliberal económica que promueve y desarrolla el proyecto de mercados globales, el imperio internacional de la ley, la democracia liberal y los derechos humanos universales como proyecto de civilización política.

En principio, alumbrar una concepción de ciudadanía cosmopolita nos conduce inexorablemente hacia una necesaria y prioritaria globalización jurídica de los derechos humanos en el nuevo orden mundial, una ciudadanía global que apenas se está gestando, desarrollando y configurando. La configuración de integraciones políticas y económicas regionales puede ayudar a configurar alianzas estraté-

${ }^{2}$ A. McGrew, «Globalization and Territorial Democracy», en A. McGraw (comp.), The Transformation of Democracy? , Cambridge, 1997. CARRIÓN RodRíGUEZ, Alejandro J., «El derecho internacional a la hora de la globalización» en Oliet PaLÁ (comp.) Globalización, Estado y Democracia, Servicio Publicaciones Universidad de Málaga, Málaga, 2003; STiglitz, J. E., El malestar en la globalización, Madrid: Taurus, 2002; CASTELLS, M., La era de la información, vol. II, El poder de la identidad, Madrid, Alianza, 1998; Bеск, U., ¿Qué es la globalización?, Barcelona: Paidós, 1998; Przeworski, A., Sustainable Democracy, Cambridge: Cambridge University Press, 1995.

${ }^{3}$ No eludo la dificultad que conlleva esta temática, pues aglutina esferas y ámbitos distintos. Por un lado, no podemos negar ni ocultar que existe una cierta inconmensurabilidad o incomunicabilidad entre los estudios jurídicos y sociológicos en materia de «ciudadanía» que, por un lado, empobrecen y marginan al Derecho de la ricas y variadas aportaciones de los estudios filosóficos y sociológicos; esta visión normativista y formalista jurídica que enclaustra y reduce el derecho a mera técnica logística y operativa de efectividad de los derechos sin ningún tipo de planteamiento profundo sobre el mismo. Vid. Pérez LuÑo, A. E., ¿Ciberciudadanía o ciudadanía.com?, Barcelona, Gedisa, 2004, 
gicas para combatir la globalización económica al mismo tiempo que puede ayudarnos a diseñar un constitucionalismo cooperativo internacional que potencie y proteja los derechos humanos a nivel local, regional y global.

En la actualidad, los conceptos de ciudadanía «ciudadanía mundial» o cosmopolitismo están sufriendo una fuerte revitalización debido a los fuertes cambios, transformaciones y tendencias emprendidos por la globalización a escala mundial. El cosmopolitismo ${ }^{4}$ no responde a una idea clara, fija y contundente, sino que requiere por un lado de una amplia tipología que distinga entre cosmopolitismo moral y político, y por otro recoja otras variedades como el cosmopolitismo federalista internacional, el cosmopolitismo legal, el cultural, el económico y el romántico ${ }^{5}$. Es evidente que las relaciones internacionales y trasnacionales están debilitando los poderes de los Estados modernos soberanos. La globalización ha generado un proceso de interconexión económica, política y jurídica que erosiona gravemente a los Estados-nación a nivel externo; pero a nivel interno, los nacionalismos locales y regionales están fragmentando los Estados-nación. Maquiavelo, en el siglo XV, contempló la fragmentación y la debilidad de los Estados italianos y apostó por su fortalecimiento y conservación como garantía segura frente al caos, la guerra y la inseguridad. Indudablemente, las amenazas son otras; pero volvemos a asistir a un debilitamiento de los Estados modernos, por diferente causa. Entonces se constituían los Estados-nación, hoy comienza su crisis crónica, en algunos casos irreversible especialmente en ciertos países de América Latina, aunque no se trata de una desintegración o desaparición completa sino de una pérdida progresiva de competencias, soberanía y poder.

En este aspecto, un sector amplio de representantes del eurofederalismo ${ }^{6}$ defienden una posición cosmopolita al considerar que un Es-

\footnotetext{
${ }^{4}$ KLEINGELD, Pauline, «Six Varieties of Cosmopolitanism in Late Eighteenth-Century Germany»; Journal of the History of Ideas, vol. 60, n. ${ }^{\circ}$ 2, 1999, pp. 505-6; Zolo, D., Cosmópolis. Perspectivas y riesgos de un gobierno mundial, (trad. R. Grasa y F. Serra), Paidos, Barcelona, 2000.

${ }^{5}$ ARamayo Roberto y Villacañas, J. L. (comps), La herencia de Maquiavelo, (modernidad y voluntad de poder), México, Fondo de Cultura Económica, 1999.

${ }^{6} \mathrm{Vid}$. Agra Romero, María Xosé, "Ciudadanía: Fronteras, círculos y cosmopolitismo» en Anales de la Cátedra Francisco Suárez, Universidad de Granada, n 36, 2002, pp. 9-28; Aguilera Portales, Rafael Enrique, «Dilemas y desafíos de la ciudadanía europea en el orden mundial: ¿hacia una Europa de los ciudadanos?» en Velásquez Ramírez, Ricardo y Bobadilla Reyes, Humberto (Cood.) Justicia Constitucional, Derecho Supranacional e integración en el Derecho Latinoamericano, Lima, Ed. Grijley, 2007, pp. 401-415.
} 
tado federal europeo puede ser el punto de partida para el establecimiento de un futuro régimen "político mundial» basado en tratados y organizaciones internacionales. A este respecto, Habermas distingue cuatro posiciones respeto al nivel de aceptación de la idea de democracia postnacional: euroescépticos, europeos partidarios del mercado, eurofederalistas y los partidarios de una global governance. Los eurofederalistas aspiran a la transformación de los tratados internacionales en una constitución política para dotar a las decisiones supranacionales de la Comisión, del Consejo de Ministros, del Tribunal Superior de Justicia Europeo y del Parlamento Europeo con su propia base de legitimidad. En el sector opuesto se encuentran los euroescépticos que se conforman y quedan satisfechos con la construcción de un mercado interior europeo, una moneda única y una política económica común. La mundialización de las relaciones políticas pone en evidencia la necesidad de un gobierno a escala planetaria. Sin duda, hay todavía esto puede parecer una cuestión demasiado utópica; pero lo cierto es que el incremento de las desigualdades sociales, la crisis energética y alimenticia, la inseguridad, el terrorismo y los conflictos internacionales está viendo aparecer el desarrollo y aparición de nuevos agentes y organizaciones internacionales ${ }^{7}$ como la Unión Europea que no responden a la imagen clásica y convencional de un Estado moderno.

En la Teoría Política contemporánea, el concepto de ciudadanía constituye una construcción social, al igual que el concepto de Estado se funda, por un lado, en un conjunto de condiciones institucionales y materiales y, por el otro, en una cierta concepción de bien común y esfera pública. Lo que equivale a decir que estamos ante un imaginario socio-jurídico que surge de una conquista progresiva y paulatina de derechos fundamentales, que redunda a su vez, en una profundización democrática de todos los aspectos de la vida social (político, económico, jurídico, académico,...). Por tanto, la ciudadanía es una construcción socio-jurídica y socio-histórica que responde a determinadas luchas y reivindicaciones históricas concretas en contextos muy específicos.

${ }^{7}$ Una nueva forma de organización social tiende a expandirse por todo el planeta transformándose en una nueva ciudad llamada telépolis o la aldea global electrónica. Las naciones y los Estados dejan de ser formas determinantes de la vida social y se forma progresivamente una aldea global gracias a las comunicaciones donde todos los ciudadanos del mundo se interrelacionan e interactúan a distancia, directa e indirectamente. El concepto proviene de MARShall MACLUHAN, Los medios de comunicación, Buenos Aires, Ed. Losada, 1988; GIDDENS, A., Un mundo desbocado. Los efectos de la globalización en nuestras vidas, trad. de P. Cifuentes, Taurus, Madrid, 1999. 
En este aspecto, podemos señalar que las características más relevantes del concepto de ciudadanía son tres componentes imprescindibles: participación, derechos y pertenencia ${ }^{8}$. En primer lugar, un ciudadano, participa e interviene en mayor o menor medida en la vida pública, por otra parte, es un sujeto titular de ciertos derechos y deberes correspondientes y, por último, es alguien que pertenece a una comunidad (no es un extranjero, ni mero residente). La ciudadanía implica la lucha por la pertenencia y participación a una comunidad, su análisis abarca el examen de los modos en que los diferentes grupos pugnaron por conquistar grados de autonomía y control sobre sus vidas en oposición a las distintas formas de jerarquía, estratificación y opresión política. En este línea, voy a tratar de analizar los tres elementos que se relacionan con la ciudadanía, en primer lugar, ciudadanía como forma de participación ético-política en una determinada comunidad y su vinculación las distintas concepciones de democracia que actualmente tenemos, en segundo lugar, la ciudadanía como desarrollo y ejercicio de derechos fundamentales y, por último, el problema o dilema de la ciudadanía entendida como derecho universal (cosmopolita) o derecho nacional (estatal).

\section{CIUDADANÍA CÍVICA Y DEMOCRÁTICA EN EL ESTADO CONSTITUCIONAL}

En primer lugar, la ciudadanía entendida como estatus jurídico nos remite habitualmente al reconocimiento por parte del Estado de los individuos del derecho al disfrute y ejercicio de derechos y libertades fundamentales en especial los referidos a los derechos civiles y políticos. Esta capacidad política y jurídica reconocida y otorgada por el Estado es la que constituye a los individuos en ciudadanos.

\footnotetext{
${ }^{8}$ Véase el excelente estudio de esta problemática del profesor PEÑA, Javier: «La formación histórica de la idea moderna de ciudadanía» en QuESADA, F., Naturaleza y sentido de la ciudadanía hoy, UNED, Madrid, 2002. Igualmente, puede consultarse el excelente estudio de Rocco Las barreras entre la antiguo y el mundo moderno se están diluyendo y borrando, el pasado se está convirtiendo en algo más permeable y un interlocutor importante a nuestro presente moderno. También puede consultarse el excelente trabajo de Rocco, Christopher, Tragedy and Enlightenment: Athenian Political Thought and the Dilemmas of Modernity, University of California Press, California, 1996. Para ampliar más sobre el tema puede consultarse LEwIS, Sian, News and Society in the Greek Polis (Studies in the History of Greece and Rome). The University of North Carolina Press, Chapel Hill, 1996; Vernant, Jean-Pierre, y Pierre Vidal-NAQUeT, Miyth and tragedy in ancient Greece, trad. Ing. Janet Lloyd, Nueva York, Zone Books, 1980; Bloom, Allan, The Republic of Plato, Nueva York, Basic Books, 1968.
} 
Esta dimensión jurídico-política entiende la ciudadanía como sujeta al ordenamiento jurídico de un determinado Estado, al ámbito de la legalidad. Sin embargo, en nuestras actuales sociedades complejas debemos replantearnos esta concepción jurídico-política de ciudadanía, a veces demasiado limitada y restringida en los procesos de integración socioeconómica y jurídica como es el caso del creciente fenómeno global de la inmigración hacia países desarrollados como Europa y Estados Unidos.

Una teoría y práctica de la ciudadanía está necesariamente conectada al concepto de los derechos humanos (civiles, políticos, sociales, económicos, culturales,...) junto al concepto de democracia, pues estos dos pilares proporcionan la base sólida del origen, desarrollo y consolidación de una ciudadanía constitucional. Por tanto, un enfoque integral de la ciudadanía debe partir necesariamente de un sistema de derechos constitucionalmente garantizados y efectivos para todos los miembros de una comunidad política, afirmando que estos derechos no deben ser sólo derechos políticos, sino también derechos económicos, sociales y culturales.

«Los derechos fundamentales, tanto los que garantizan libertades individuales como los de participación política, fundamentan es estatuto de ciudadano, estatuto que entretanto se ha vuelto autorreferencial, en la medida que habilita a los ciudadanos unidos democráticamente a conformar su propio estatus mediante la autolegislación.» ${ }^{9}$

Sin lugar a dudas, esta concepción moderna de ciudadanía ligada a los derechos fundamentales constituye una herencia de la tradición y el legado grecorromano, y más específicamente, del Derecho romano. El ciudadano romano es un sujeto de derechos en terreno familiar, económico, judicial, religioso (Corpus Iuris Civilis). La república era definida por Cicerón como asociación de hombres unidos

${ }^{9}$ Cfr. Habermas, J., La constelación postnacional, (trad. Cast. Pere Fabra Abat, prólogo Camps, V.), Paidós, Barcelona, 2000, p. 103. El profesor PEREz LuÑo, A. E. subraya diferencia existente entre los estudios jurídicos y los estudios filosóficos sobre la categoría de ciudadanía, mientras los primeros entienden la ciudadanía como institución que emana del derecho positivo estatal (derecho constitucional y administrativo) y son de orden descriptivo, los segundos revisten el significado deontológico y contrafáctico de un modelo ideal de estatus que debe reconocerse a los miembros de la sociedad política (concepción prescriptita). Un ejemplo notorio de esta acepción de significado de ciudadanía descriptiva es la defendida por Rudolf Smend en la Universidad de Berlín que se desprende de la Constitución de Weimar. Véase SMEND, Rudolf, Ciudadano y burgués en el derecho político alemán. 
por un ordenamiento jurídico ${ }^{10}$. La república es asunto del pueblo, pero pueblo no significa una simple reunión de hombres congregados de forma azarosa y arbitraria, sino un cuerpo ordenado y regulado bajo las garantías de las leyes con un objetivo común de utilidad pública, de este modo, se concebía la ley como lazo y factor de ordenación de la sociedad civil. El advenimiento de la jurisprudencia traslada el concepto de "ciudadano» polités griego al civis latino, del zoón politikón al homo legalis, como afirma Pocock; pero aunque encontremos las raíces de la ciudadanía en Grecia y Roma, el concepto actual de ciudadano proviene con mayor fuerza de la modernidad y, más concretamente, de las revoluciones inglesa, francesa y americana.

El movimiento moderno de la Ilustración planteó dos tradiciones en su seno, la tradición republicana cosmopolita, de signo claramente kantiano, que parte de la concepción de dignidad, autonomía y no instrumentalización de los hombres; y la tradición política nacionalista, de signo herderiano, que concibe la nación o el pueblo como una entidad colectiva natural, dotada de espíritu propio (volkgeist) que contiene elementos más emocionales o sentimentales que estrictamente jurídicos ${ }^{11}$.

La ciudadanía consiste en la titularidad y ejercicio de los derechos ciudadanos: civiles, políticos y sociales, que están íntimamente rela-

${ }^{10}$ Cfr. Ciceron, Sobre la República, I, 25,39. En este sentido, existe una corriente de juristas romanistas que hablan de un retorno al civis romano. Con la caída del Imperio Romano se perdió la idea de ciudadanía como pertenencia a una comunidad política. El cristianismo favoreció el distanciamiento de la comunidad política (repliegue sobre el ámbito privado, ámbito de salvación eterna). San Agustín nos hablaba de una doble ciudadanía entre la civitas terrrans y la civitas dei que determinaron el paradigma de pensamiento medieval del medioevo hasta la entrada de la modernidad.

${ }^{11}$ Esta concepción de ciudadanía como pertenencia sentimental (etnos, ethos) es reivindicada por la tradición comunitarista que tiene como presupuesto ideológico la tradición nacionalista herderiana en oposición al pensamiento liberal que entiende la ciudadanía como concepto más político y jurídico (demos), como vínculo que surge de la relación contractual (pacto social). El debate o polémica en torno a la concepción de ciudadanía lo protagonizan pensadores liberales como J. Habermas, J. Rawls, R. Dworkin, K.O. Popper, K. O. Apel frente a los comunitaristas como Ch. Taylor, M. Walzer, A. MacIntyre, M. Sandel, R. Rorty, B. Barber. A lo largo de estos últimos años se ha podido apreciar como estas posiciones no son sólo concepciones filosóficas morales y políticas antagónicas, sino que conllevan y reflejan una visión hermenéutica del entramado social, político y jurídico de nuestras sociedades complejas. Aunque conviene precisar que no podemos considerar al grupo de los teóricos liberales y comunitaristas como si fuesen un conjunto compacto y homogéneo, porque, evidentemente, existen profundas diferencias entre ellos. El incluirlos en grupos atiende más bien a situarlos en dos tradiciones distintas y enfrentadas dentro del panorama de pensamiento actual. Para profundizar sobre éste debate véase el trabajo 
cionados con el sistema de gobierno y la estructura social y económica de un país determinado. El gran teórico contemporáneo Thomas H. Marshall ha abordado el carácter multidimensional de ciudadanía $^{12}$, compuesta como mínimo por tres elementos: civil, político y social. Marshall sostiene que los derechos ciudadanos han sido una construcción socio-jurídica dentro de un largo proceso histórico. La construcción de la ciudadanía ha recorrido tres etapas históricas: los derechos civiles del siglo XVIII, derechos políticos del siglo XIX y, un último estadio, los derechos sociales en el siglo XX. Sin lugar a dudas, el movimiento ilustrado del siglo XVIII significó la conquista de la ciudadanía civil (derechos civiles): los derechos que promueven el imperio del derecho como el derecho a un juicio justo, acceso igualitario a la justicia derecho de propiedad privada, las garantías de indemnización en caso de expropiación, el habeas corpus. El siglo XIX fue la construcción de la ciudadanía política: los derechos de participación política, derechos de sufragio, de expresión, de asociación, el derecho al ejercicio del poder político «elegir y ser elegido». En el siglo XX se accede a la formación de la ciudadanía social (derechos sociales). Estos derechos sociales aluden a la garantía y disfrute por parte de los ciudadanos de la titularidad y ejercicio de ciertos estándares históricos, económicos y sociales de un modelo de sociedad de bienestar.

\section{DISTINTOS MODELOS DE CIUDADANÍA POSTNACIONAL}

\section{III.1. Modelo de patriotismo constitucional de Jürgen Habermas}

Habermas defiende la concepción de «patriotismo constitucional» ${ }^{13}$ como el único patriotismo legítimo que encuentra sus límites

${ }^{12}$ Marschall, Th. H., Cititzenship and Social Class, 1950, (trad. cast. Marschall, Th. H, y Bottomore, T. Ciudadanía y Clase social, (trad. Pepa Linares), Alianza Editorial, Madrid, 1998. En esta obra define la ciudadanía como posesión de derechos y pertenencia a una comunidad. La noción marshalliana de ciudadanía se inscribe en la tradición ética-comunitarista-republicana que tiene como antecedentes a Aristóteles, Maquiavelo y Rousseau.

${ }^{13}$ El concepto de "patriotismo constitucional» fue utilizado por primera vez por STERNBERGER, Dolf, Schrifen, vol. X: Verfassungspatriotismus, aus dem Nachlab herusgegeben von P. Haungs, K. Lnadfried, Ed. Orth und B. Vogel. Frankfurt am Main, Insel, 1990. Sternberger propone en 1979 la idea de patriotismo constitucional, si bien esta sólo sería posteriormente divulgada con éxito por Jünger Habermas. La reflexión de Sternberger surge ante la necesidad histórica del pueblo alemán de superar errores históricos y reconstruir un sistema político nuevo claramente expresado en la Constitución alemana de 1949, pero sobre todo para inspirar una nueva forma 
en los postulados de universalización de la democracia y los derechos fundamentales. «El nacionalismo quedó extremado entre nosotros en términos de darwinismo social y culminó en un delirio racial que sirvió de justificación a la aniquilación masiva de los judíos. De ahí que el nacionalismo quedara drásticamente devaluado entre nosotros como fundamentos de una identidad colectiva» ${ }^{14}$.

Por universalismo Habermas entiende: «que se relativiza la propia forma de existencia atendiendo a las pretensiones legítimas de las demás formas de vida, que se reconocen iguales derechos a los otros, a los extraños, con todas sus idiosincrasias y todo lo que en ellos nos resulta difícil de entender, que uno no se empecina en la universalización de la propia identidad, que uno no excluye y condena todo cuanto se desvíe de ella, que los ámbitos de tolerancia tienen que hacerse infinitamente mayores de lo que son hoy; todo esto es lo que quiere decir universalismo moral ${ }^{15}$.

Habermas utiliza tres categorías básicas: «Etnos», "ethos», "demos». El componente del «etnos» define cualquier comunidad desde los elementos prepolíticos-jurídicos de tipo natural, sean étnicos, racionales, religiosos, lingüísticos o culturales. En esta categoría se incluyen realidades tan diferentes como las naciones, las minorías lingüísticas o raciales, las religiones, los trabajadores extranjeros inmigrantes, las mujeres, los homosexuales, los discapacitados, etc. El componente del "ethos» comprende las diferentes concepciones morales de lo que es bueno, diferentes cosmovisiones que arropan una determinada comunidad. El tercer elemento es el «demos» que significa la comunidad de ciudadanos libres dentro de una organización política que participa políticamente.

Habermas propugna la vinculación de las primeras, «etnos» $\mathrm{y}$ «ethos», y su radical separación de la tercera «demos». Al componente «etnos» suele corresponder un determinado «ethos», el «demos» se fundamenta en un compromiso ciudadano ajeno a los problemas éticos respecto de los cuales la política ha de mantenerse natural. «La

pluralista e integradora, de identidad colectiva y aglutinar en torno a un proyecto político colectivo una nación escindida y traumatizada por la barbarie del nazismo y la Segunda Guerra Mundial. Gómez GARcía, Juan Antonio: «La estructura filosófica de los modelos procedimentalistas de justicia: los modelos de 'ética discursiva' de Jürgen Habermas y de Karl-Otto Apel», en Anales de la Cátedra Francisco Suárez, Universidad de Granada, núm. 40, 2006, pp. 171-182.

${ }^{14}$ Cfr. HABERmas, J. Identidades nacionales y postnacionales, Madrid, tecnos, 2002, p. 116.

${ }^{15}$ Ibid., p. 117.

(C) UNED. Revista de Derecho UNED, núm. 8, 2011 
ciudadanía democrática -dice Habermas- no ha de menester quedar enraizada en la identidad nacional de un pueblo; (...) y con independencia de y, por encima de, la pluralidad de formas de vida culturales diversas, exige la socialización de todos los ciudadanos en una cultura política común ${ }^{16}$. En este aspecto, Estados Unidos y Suiza son los ejemplos de esta ciudadanía democrática, según Habermas.

El «patriotismo constitucional» consiste en la lealtad a la Constitución y a la comunidad política democrática y, en consecuencia, ajena a todo elemento o contaminación ética o étnica. Si bien Habermas reconoce la inevitabilidad de tales impregnaciones y contaminaciones etnoculturales y morales no quiere definir la ciudadanía desde estos elementos contingentes, plurales y relativos. En este sentido, Habermas han destacado los elementos procedimentales que favorecen la prioridad de la justicia sobre el bien, o que las cuestiones de justicia ( $l$ lo que es bueno para todos») están separadas de aquellos preceptos éticos o concepciones del bien particulares («lo que es bueno para mí o para nosotros»). Mientras que los pensadores comunitaristas, desde su contextualismo extremo, el concepto de justicia está íntimamente ligado a la noción de bien y no cabe separación posible. Habermas considera que el pluralismo de las cosmovisiones de la sociedad actual es un pluralismo ético y étnico, que requiere de una neutralización de lo político si queremos conservar y mantener dicho pluralismo moral, político y cultural. De este modo, el patriotismo constitucional se opone al nacionalismo que toma el concepto de Nación como categoría política fundamental. La conciencia nacional se reduce a una dimensión ética y, por tanto, particular, cuyos rasgos, lenguaje, literatura, historia constituyen diversas tradiciones.

Jürgen Habermas, inscrito en la filosofía jurídica kantiana cosmopolita apunta a la misma idea: «Sólo una ciudadanía democrática que no se cierre a términos particularistas puede, por lo demás, preparar el camino para un status de ciudadano del mundo o una cos-

${ }^{16}$ Cfr. Habermas, J., Facticidad y Validez, Madrid, Trotta, 1998, p. 629. La reconstrucción de la esfera política, para Habermas, pasa necesariamente por la vertebración de una sociedad civil, la potenciación y desarrollo de una cultura política, y la regeneración del espacio público a través de la opinión pública que genere una nueva voluntad política. GómEz GARCíA, Juan Antonio: «Fundamentación de la democracia a propósito de la dialéctica legalidad-legitimidad: relación estructural entre la sociología política weberiana y los modelos procedimentalistas de ética discursiva», en AGUILERA Portales, Rafael Enrique (Coord.): La democracia en el Estado constitucional (Nuevos enfoques y análisis). México, Porrúa, Universidad Autónoma de Nuevo León, 2009, pp. 22-44. 
mociudadanía, que hoy empieza ya a cobrar forma en las comunicaciones políticas que tienen un alcance mundial ${ }^{17}$.

El concepto de "patriotismo constitucional» ${ }^{18}$ representa, sin embargo, un modelo de afirmación de los principios políticos democráticos y liberales y la supremacía constitucional sobre la propia cultura, historia y tradición de un pueblo. En este sentido, el amor a la patria viene expresado como amor al Estado de derecho y sus valores constitucionales que priman o se superponen sobre los elementos étnicos o socio-culturales de una determinada comunidad política. Charles Taylor ${ }^{19}$ entra en polémica con Habermas respeto a la cuestión de tratar de conciliar los derechos colectivos y culturales con los derechos individuales de primera generación. Habermas está convencido de que los derechos grupales, es decir, los derechos que surgen del respeto de ciertos grupos sociales en desventaja en una sociedad mayoritaria, derivan del respeto a la identidad individual y por tanto, de los derechos individuales. Por consiguiente, rechaza la fundamentación ética y jurídica de Taylor, haciendo hincapié en la falacia normativa desde el punto de vista jurídico de la defensa de derechos colectivos.

«No se necesita, por tanto, que la coexistencia en igualdad de derechos de los distintos grupos étnicos y sus formas de vida cultural se asegure por medio de derechos colectivos, que llevarían a sobrecargar una teoría de los derechos cortada a la medida de las personas individuales» ${ }^{20}$.

${ }^{17}$ Ibid., p. 643. Para profundizar en el impacto del pensamiento federalista a nivel internacional y en el proceso de integración europea consultar el trabajo AGUILERA PORTALES, Rafael Enrique, «La encrucijada de una ciudadanía constitucional europea a través del pensamiento federalista» en Torres Estrada, Pedro (ed.) La Reforma del Estado, Editorial Porrúa, México, 2007. Igualmente puede verse Olivas Cabanillas, Enrique, "Globalización y derecho: una aproximación desde Europa y América Latina» en Dilex, 2007

${ }^{18}$ Vid. ABELLÁN, Joaquín, «Los retos del multiculturalismo para el Estado moderno» en Badillo O’Farrell, Pablo (cood.), Pluralismo, tolerancia, multiculturalismo, Universidad Internacional de Andalucía, Akal, Madrid, 2003. STERNBERGER quería sentar sobre la concepción de «patriotismo constitucional» habermasiana el proyecto de unificación política alemana entre la RFA y RDA, entendiendo la noción esencialmente como «nación política», o sea, orden constitucional democrático y no «nación étnicocultural». El nacionalismo alemán quedaría totalmente devaluado como fundamento de identidad colectiva de los alemanes por causa del delirio racial y el holocausto nazi. Véase Habermas, J., Identidades nacionales y postnacionales, Madrid, 1989.

${ }^{19} \mathrm{Vid}$. TAYLOR, Charles, Multiculturalism and "the politics of recognition», A. Gutman ed. Princeton, Princeton University Press, 1992. Véase otros trabajos suyos donde analiza esta cuestión: Ética de la autenticidad. Paidós, Barcelona, 1998; Argumentos filosóficos, Paidós, Barcelona, 2000

${ }^{20}$ Cfr. Habermas, J., La inclusión del otro, Estudios de teoría política, Barcelona, Paidós, 1999, p. 210. 
En realidad lo que le preocupa a Habermas es que el individuo como sujeto se encuentre sometido o coartado dentro de una determinada tradición cultural o comunidad local, sobre todo, cuando esa visión cultural puede incluir costumbres brutales que vulneren claramente los derechos individuales de un determinado ciudadano.

«Es radicalmente impracticable, porque no tiene en cuenta en absoluto las condiciones reales de la vida de los hombres, que se desarrolla en comunidades constituidas ${ }^{21}$. Los individuos elaboran su identidad, individual y colectiva, en una comunidad nacional concreta. La adhesión intelectual a principios abstractos como -derechos humanos, respeto al Estado de derecho- no podrá reemplazar la movilización política y afectiva que suscita la interiorización de la tradición nacional y cultural. Para Charles Taylor la movilización ciudadana sólo se produce en torno a identidades comunes, en su mayor parte, en torno a identidades locales frente a identidades abstractas hacia las cuales no sienten lealtad. La tradición del humanismo cívico siempre ha sostenido que las sociedades libres, dependen del apoyo espontáneo de sus miembros, es decir, necesitan el fuerte sentido de lealtad al que Montesquiu llamó «virtud».

\section{III.2. Modelo de ciudadanía posnacional y universal de Luigi Ferrajoli}

Desde la filosofía política y jurídica, Luigi Ferrajoli ${ }^{22}$ habla explícitamente de los derechos de los pueblos en relación con la crisis actual de la soberanía estatal. Los Estados actuales están siendo gravemente cuestionados en su soberanía nacional frente a los procesos de globalización. Ferrajoli subraya cómo el paradigma del viejo Estado soberano es inadecuado y obsoleto ${ }^{23}$ al imparable proceso de globalización política y jurídica. Y la razón fundamental de esa crisis ha

${ }^{21}$ Cfr. Schnapper, Dominique, La comunidad de los ciudadanos (Acerca de la idea moderna de nación) Alianza Editorial, Madrid, 2001, p. 77.

${ }^{22}$ Cfr. Ferrajoli, Luigi, Derechos y garantías. La ley del más débil, Ed. Trotta, Madrid, 1999, p. 145.

${ }^{23} \mathrm{Vid}$. CARRIÓN ROdRíguez, Alejandro J., «El derecho internacional a la hora de la globalización» en Oliet Palá (comp.) Globalización, Estado y Democracia, Servicio Publicaciones Universidad de Málaga, Málaga, 2003, p. 276. Aunque también tenemos precisar en oposición a los análisis apocalípticos de los Estados-nación, como afirma el eminente sociólogo Ralf Dahrendorf y Adair Turner, que los gobiernos nacionales todavía tienen aún más margen de maniobra de lo querrían hacernos creer algunas exageradas descripciones de la globalización, véase en Dahrendorf, R., Después de la democracia, FCE, México, p.21. 
sido que en el nuevo derecho internacional «pasan a ser sujetos de derecho internacional no sólo los Estados, sino también los individuos y los pueblos» que reconoce tanto la Declaración de 1948 y los Pactos de 1966, donde expresamente se afirma el derecho de autodeterminación de los pueblos. La Declaración universal de los derechos de los pueblos de Argel de 4 de Julio de 1978 afirma que «el respeto efectivo de los derechos humanos implica el respeto de los derechos de los pueblos» ${ }^{24}$.

La modernidad occidental ha considerado siempre el concepto de ciudadanía como un concepto ligado al de derechos humanos, de forma tal, que los derechos del hombre y del ciudadano se marcaron, desde un inicio, como indisolublemente unidos y vinculados. Esta lucha y conquista de los derechos humanos que durante décadas han realizado los hombres y las sociedades pueden verse reflejados en el reconocimiento de los derechos fundamentales tanto a nivel nacional como internacional.

Las primeras Declaraciones de derechos, tanto la Declaración francesa como las Declaración americana de 1776. La primera Declaración de los derechos del Hombre que sirve de preámbulo a la Constitución del Estado de Virginia del 12 de junio de 1776, cuyo espíritu se encuentra en la mayoría de las constituciones de América Latina proclama como los hombres son «libres e independientes por naturaleza», que poseen derechos inalienables que limitan el poder del Estado y que el fundamento de la legitimidad política se encuentra, según la tradición contractualista, en el acuerdo de los individuos en torno de la necesidad de un gobierno encargado de garantizar esos derechos. Precisamente, en estas Declaraciones se configuró los derechos de ciudadanía como derechos humanos fundamentales. Los conceptos de soberanía y ciudadanía continúan informando las relaciones de conflicto y cohabitación, exclusión e inclusión que existen entre los Estados, los pueblos y las personas.

Estas primeras declaraciones fueron producto de utopías jurídicas que se plasmaron posteriormente con la supresión de las desigualdades que el antiguo régimen había instaurado y fijaron el inicio de la historia del constitucionalismo y la democracia moderna. De esta

${ }^{24}$ Declaración universal de los derechos de los pueblos de Argel de 4 de Julio de 1978; Véase también KUNG, H., Proyecto de una ética mundial, Trotta, Madrid, 1998. El profesor Hans Hung plantea una ética política universal desde el dialogo intercultural entre los pueblos siguiendo el cosmopolitismo republicano kantiano de un Federalismo libre de todos los pueblos que vendría anunciado incialmente como la actual organización de Naciones Unidas. 
forma, vemos cómo la historia del derecho es también una historia de utopías (mejor o peor) convertidas en realidad.

Estos derechos de residencia y circulación, como apunta Ferrajoli, habían sido proclamados como universales en los orígenes de la modernidad por nuestra misma cultura occidental. En 1539, en sus Relectiones de Indis recenter inventis impartidas en la Universidad de Salamanca, Francisco de Vitoria reformulaba los títulos de legitimación de conquista de América por parte de los españoles sentando las bases del moderno derecho internacional y, al mismo tiempo, de la posterior doctrina de los «derechos naturales». Estos títulos de legitimación se encontraban en el ius communicationes ac societatis, que él situaba en la base de su concepción de la sociedad internacional como comunitas orbis hermanada por el derecho de todos a comunicar con todos, y en una larga serie de otros derechos naturales que él formulaba como sus corolarios: el ius peregrinndi in illas provincias et illic degendi, el ius comercii, el ius praedicanddi e annunciandi Evangelium, el ius migrandi hacia los países del Nuevo Mundo $\mathrm{y}$ al accipere domicilum in aliqua civitate illorum ${ }^{25}$.

En la crisis de los Estados y de las comunidades nacionales que caracteriza este fin de siglo, conectada con fenómenos paralelos como la migraciones de masas, los conflictos étnicos y la distancia cada vez mayor entre Norte y Sur, es preciso reconocer que la ciudadanía ya no es, como en los orígenes del Estado moderno, un factor de inclusión e igualdad. Por el contrario, cabe constatar que la ciudadanía en los países ricos representa un verdadero privilegio de status, el último factor de exclusión y discriminación, el último residuo premoderno de la desigualdad personal en contraposición a la proclamada universalidad e igualdad de los derechos fundamentales.

Sin lugar a dudas, nuestra cultura ha olvidado los orígenes de esa modernidad jurídica e ilustrada, Luigi Ferrajoli ve claro como los derechos - peregrinandi, migrandi, degendi-fueron proclamados como iguales y universales. El derecho de residencia, movilidad y libre circulación ${ }^{26}$ deben ser reconocidos como un derecho legítimo que su-

${ }^{25}$ Vid. FerRajoli, Luigi, Derechos y garantías... op. cit., p. 147; Véase también FeRRAJOLI, L, Derecho y razón. Teoría del galantismo penal, (trad. Cast. De P. Andrés Ibáñez y otros), Trotta, Madrid; Véase para ampliar o profundizar sobre la teoría jurídica de Ferrajoli el trabajo: Aguilera Portales, Rafael y LóPez SÁnchez, Rogelio, "Los Derechos fundamentales en la Teoría Jurídica garantista de Luigi Ferrajoli», Revista jurídica Iustitia, Instituto Tecnológico de Monterrey, 2007, no 14, pp. 67-93.

${ }^{26}$ Como ha destacado el filósofo del Derecho Ferrajoli en «De los derechos de los ciudadanos a los derechos de la persona» en FerRaJoli, L., Derechos y garantías, Trotta, Madrid, p.98. 
pera fronteras, Estados y continentes. Aunque, todos somos conscientes que el problema de subdesarrollo que vive América Latina no se resuelve abriendo las fronteras de Europa y EEUU, sino aportando soluciones políticas de desarrollo sustentable y cooperación internacional a este rico continente americano.

Los derechos se han convertido en derechos de ciudadanía exclusivos y privilegiados, a partir del momento en que se trató de tomarlos en serio y de pagar su coste. «Tomar en serio estos derechos significa hoy tener el valor de desvincularlos de la ciudadanía como pertenencia (a una comunidad estatal determinada) y de su carácter estatal. Y desvincularlos de la ciudadanía significa reconocer el carácter supra-estatal en los dos sentidos de su doble garantía constitucional e internacional- y por tanto tutelarlos no sólo dentro sino también fuera y frente a los Estados, poniendo fin a este gran apartheid que excluye de su disfrute a la mayoría del género humano contradiciendo su proclamado universalismo ${ }^{27}$ Hoy por hoy, en un contexto de explosión demográfica, aumento de la pobreza y la desigualdad en América Latina, la solución aportada por el filósofo del Derecho Luigi Ferrajoli no es reducir los derechos del hombre a los derechos ciudadanos y al mismo tiempo pretender fundar aún sobre la ciudadanía la lucha por los derechos en nombre del universalismo, sino reconocer estos derechos como universales y cosmopolitas. La antinomia entre la universalidad de los derechos y la ciudadanía se resolverá mediante la superación de la ciudadanía y la desnacionalización de los derechos humanos, un exponente de este problema viene a través del derecho de asilo. El derecho de asilo fue restringido a personas sujetas a persecuciones políticas, raciales o religiosas y no se aplica a refugiados por motivos de derechos económicos o de subsistencia. Esta limitación jurídica refleja el gado paleolítico constitucional en el que nos encontramos actualmente. Sólo son reconocidos los derechos políticos y de libertades negativas los reconocidos para solicitar el derecho de asilo, cuando las constituciones europeas han evolucionada hacia el reconocimiento de un amplio abanico de derechos de todo tipo, incluidos los derechos relacionados con la subsistencia o supervivencia.

${ }^{27}$ Cfr. FerRAJOLI, Derechos y garantías, op. cit., p. 97.La propuesta de Ferrajoli trata de romper la tendencia consolidada en el Constitucionalismo y la teoría de los derechos fundamentales, de establecer una nítida demarcación entre estos derechos y los derechos subjetivos privados, como expresa el profesor Antonio Enrique Pérez Luño: « los derechos humanos poseen una insoslayable dimensión deontológica. Se trata de aquellas facultades inherentes a la persona que deben ser reconocidas por el derecho positivo» Cfr. PÉREz LuÑo, A. E., ¿Ciberciudadanía o ciudadanía.com?, Barcelona, Gedisa, 2004, p. 45. 


\section{III.3. Modelo de ciudadanía constitucional mundial de Peter Häberle}

Históricamente, desde un punto de vista jurídico se ha distinguido entre status civitatis (ciudadaní) y status personae (personalidad), Hombre y ciudadano, Homme y citoyen conforman dos clases diferentes de derechos fundamentales: derechos de personalidad, que corresponden a todos los seres humanos como individuos o personas, y derechos de ciudadanía que corresponden de forma exclusiva a los ciudadanos, es decir, pertenecientes a una comunidad nacional concreta. No obstante, los derechos fundamentales constituyen, de este modo, la categoría jurídica que engloba a los derechos humanos universales y los derechos ciudadanos nacionales. Ambas clases de derechos fundamentales son, parte integrante, necesaria e ineludible de la cultura jurídica de todo «Estado Constitucional». Los derechos, entendidos como derechos de todo ser humano de todas las naciones, incluyendo los llamados «apátridas» tienen su origen en el Estado Constitucional nacional y en la humanidad universal.

Desde esta perspectiva, el profesor Peter Haberle manifiesta: «El status mundialis (universal) de los derechos fundamentales irradia hacia el status civilis y culturalis ${ }^{28}$. Los nacionalismos son una ideología todavía presente y de mucha efectividad política. En general todos los nacionalismos afirman que el derecho de las naciones o de los pueblos a su soberanía es un derecho determinante de los derechos individuales.

Los derechos fundamentales constituyen, de este modo, la categoría jurídica que engloba a los derechos humanos universales y los derechos ciudadanos nacionales. Ambas clases de derechos fundamentales son, parte integrante, necesaria e ineludible de la cultura jurídica de todo «Estado constitucional» ${ }^{29}$. El Estado constitucional

${ }^{28}$ El profesor Peter HÄBERLE afirma al respecto que no puede haber una primacía de los derechos nacionales del ciudadano sobre los derechos universales. No se puede crear, interpretar ni desarrollar los «derechos fundamentales propios» sin los derechos humanos universales, de este modo, ve cómo en algunas Constituciones los derechos humanos internacionales prevalecen sobre los derechos fundamentales nacionales. Vid. HäBerle, P., El Estado constitucional, (trad. Héctor Fix-Fierro), Universidad Nacional Autónoma de México, UNAM, México, 2001. En el preámbulo de la Convención Americana sobre Derechos Humanos (1969) se encuentra la siguiente frase: «Reconociendo que los derechos esenciales del hombre no nacen del hecho de ser nacional determinado Estado, sino que tienen como fundamento los atributos de la persona humana».

${ }^{29}$ Es oportuno precisar que «Estado constitucional de Derecho» y «Estado de Derecho» en sentido fuerte no son términos sinónimos, sino como bien ha señalado el 
pretende internalizar los derechos humanos en su sentido universal de una forma peculiar al convertirlos en fines prioritarios de la educación política y constitucional, y una generar nueva pedagogía constitucional que configure una nueva ciudadanía. En el fondo, educar a los ciudadanos desde una cultura fuerte, sólida y madura de los derechos humanos es propiciar y buscar educarlos como «ciudadanos del mundo» ${ }^{30}$.

El filósofo ilustrado de Könisberg, Inmanuel Kant ideó un auténtico proyecto de civilización político-jurídica. Inmanuel Kant aspiraba a la creación de una seguridad jurídico universal basada en una Federación de Estados libres (lo que actualmente es Naciones Unidas), es decir, «una comunidad pacífica universal» regulada por el Derecho público cosmopolita. «Con ello, Kant introduce en la teoría del Derecho una tercera dimensión, una innovación de gran trascendencia: junto al derecho estatal y al derecho internacional, coloca el derecho cosmopolita».

Esta confederación pacífica sería posible entre Estados republicanos; es decir, lo que actualmente podemos entender como Estados Constitucionales, no gobernados de forma despótica ni autoritaria, y garantes de los derechos fundamentales. El profesor Peter Häberle traduce ese federalismo cosmopolita kantiano en una "Comunidad mundial de Estados constitucionales» ${ }^{1}$. El modelo de Estado constitucional se convierte, desde esta perspectiva cosmopolita, en un modelo extrapolable, extensible y universalizable a cualquier contexto cultural, histórico y político determinado. De este modo, el profesor Häberle nos habla de «Estado constitucional cooperativo» 0 "federalismo internacional cooperativo».

profesor Luigi FerRAJOLI, dos modelos normativos diferente. Véase FERRAJOLI, Luigi, "Pasado y futuro del Estado de Derecho» en CARBonell, M., Neoconstitucionalismo (s), Madrid, Trotta, 2003. También puede consultarse el artículo del profesor Peralta, Ramón: Sobre la naturaleza del Estado Constitucional, Revista de Estudios Políticos num125, Julio-Septiembre 2004, p. 255.

${ }^{30}$ Vid. Fernández García, E., Dignidad humana y ciudadanía cosmopolita, Instituto de Derechos Humanos «Bartolomé de las Casas», Universidad Carlos III de Madrid, Dykinson, Madrid, 2001. HÂBerle, Peter, El Estado Constitucional, Universidad Nacional Autónoma de México, México, 2001. Peter Haberle interpreta cómo la teoría de la Constitución, entendida como ciencia jurídica de los textos y la cultura, puede asociarse con una "filosofía de las imágenes», ya que la teoría del derecho del Estado trabaja tanto con la «imagen de hombre», «imagen del Estado» y la «imagen del mundo». 


\section{III.4. Modelo de ciudadanía postnacional y cosmopolita de David Held}

Igualmente, David Held ${ }^{31}$ ha realizado una crítica muy aguda sobre la concepción de una ciudadanía limitada a los derechos individuales en el interior de los Estados-nación. El profesor David Held observa como el proceso de globalización ha incrementado la separación entre una ciudadanía nacional con derechos atribuidos dentro de esos límites y el desarrollo de una legislación internacional que puede proteger, quizás mejor, los derechos fundamentales. La concepción de ciudadanía moderna ligada y definida por unos derechos universales más que por su pertenencia étnica y territorial a un determinado Estado nacional se está reestructurando en un nuevo contexto internacional propiciado por la globalización tecnológica y la mejora de las comunicaciones a nivel planetario. La globalización tiende a desarraigar a las personas, las cosas, las ideas. Todo tiende actualmente a desarraigarse, desplazarse más allá de las fronteras, de las lenguas nacionales, de los himnos, las banderas, tradiciones, héroes. Poco a poco predomina el espacio global en un tiempo constantemente presente. Nos encontramos en un imparable proceso de desterritorialización, como una característica esencial de la sociedad global. La democracia que ha estado ligada históricamente al principio de autodeterminación de los Estados modernos, comienza a perder legitimidad, pues los procesos de globalización la debilitan. Las decisiones adoptadas por la Unión Europea, la organización del Atlántico Norte (OTAN) o el Fondo Monetario Internacional (FMI) disminuyen en muchos casos el alcance de las decisiones adoptadas por los Estados-nación.

La ciudadanía global tiene que contar con las instituciones capaces de asegurar el control popular sobre las decisiones políticas. En este sentido, la democracia cosmopolita ${ }^{32}$ ya ha dejado de ser un simple fantasma o una utopía, aun cuando nos encontremos todavía bien lejos de su plena realización. La democracia cosmopolita implicaría la existencia de un amplio marco de instituciones políticas y sociales autónomas como estados, regiones, asociaciones libres, organizaciones no gubernamentales, ciudades, agencias transnacionales. Las discusiones actuales sobre la reforma de Naciones Unidas ponen de manifiesto la necesidad de generar un orden político internacional

${ }^{31}$ Vid. Held, D. y McGrew. A, Globalization/ Antiglobalization. Cambridge, Poliy Press, 2002; Held, D., (ed.) Prospect for Democracy, Cambridge, Polity, 1993.

${ }^{32}$ Cfr. FerRajoli, Luigi, Derechos y garantías, op. cit., p. 95. 
frente al vacío de poder democrático. El marco general estaría representado por una Organización de Naciones Unidas más fuerte y más democrática a partir del fortalecimiento de la Asamblea frente al excesivo poder del Consejo de Seguridad. Held incluso no descarta la introducción del sistema europeo de voto proporcional al tamaño de la población y propone la creación de una segunda cámara de la ONU -el Foro Global de la sociedad civil- conformada por asociaciones ciudadanas, movimientos sociales, organizaciones internacionales y no gubernamentales significativas a nivel internacional. Estas reformas políticas darían píe a la existencia en un futuro de un Parlamento global, con capacidades fiscales que permitirían la desmilitarización de los estados y elaboración de políticas públicas globales contra la pobreza mundial, el endeudamiento progresivo de ciertos estados, la falta de salud y educación.

El desafío de la multiculturalidad, por tanto, no se encuentra en espacios lejanos, sino en nuestra propia aldea global, nos encontramos inmersos en una época de mestizaje y mezcla de diversidades culturales, somos el resultado y producto de un enorme collage. «Por este motivo, de su efectiva universalización dependerá en el futuro próximo la credibilidad de los valores de Occidente: la igualdad, los derechos de la persona, la propia ciudadanía» ${ }^{33}$. En definitiva, se trata de completar el programa moderno político y jurídico de los derechos humanos a escala universal como expresión ineludible de una ciudadanía democrática mundial. En este sentido, la democracia no es solamente una orden socio-jurídico, sino también una cultura, un universo de actitudes, creencias, convicciones que impregna toda la sociedad tanto en su esfera tanto privada como pública. «La virtud cívica como espina dorsal de la democracia se perfila, cada vez más, como la aportación más deseable para mitigar algunos de los principales males que hoy la acucian. ${ }^{34}$

Las tendencias globalizadoras comienzan a desvincular la práctica tradicional de la democracia de sus tradicional estructura de Estado/sociedad y debemos reconocer que existen prácticas políticas actuales de democracia cosmopolita como por ejemplo las conferencias globales organizadas bajo el auspicio de Naciones Unidas para abor-

${ }^{33}$ Cfr. Ferrajoli, Luigi., op. cit., p.98.

${ }^{34} C f r$. GINER, Salvador, "Cultura republicana y política del porvenir» en GINER, S., Arbós X., y otros La cultura de la democracia: el futuro, Barcelona, Ariel, 2000, 137172, p. 137; Habermas, J., La necesidad de revisión de la izquierda, Madrid, Tecnos, 1991. Ver también Escritos políticos, Ed. Península, Barcelona, 1988; Dworkin, Ronald, La comunidad liberal, Universidad de los Andes, 1996. 
dar temas importantes como la situación de la mujer, el desarrollo, la población y el medio ambiente. Estos son experimentos políticos innovadores que no sólo anuncian la existencia de una ethos democrático cosmopolita, sino la posibilidad de poder solucionar problemas locales desde soluciones globales. En la actualidad, existe una necesidad de la democracia cosmopolita entendida como red de instituciones más complejas que asegure la influencia real de los ciudadanos sobre las decisiones que les afectan. Aunque, Held no considera irrelevante ni el Estado ni el principio de soberanía tradicional, aunque son insuficientes para el ejercicio de los derechos ciudadanos. El ser ciudadano de un Estado y el ser ciudadano del mundo constituyen un continuum cuyos perfiles empiezan al menos a dibujarse. La ciudadanía mundial está apenas esbozando, pensada, prometida, imaginada.

La evolución histórica de la ciudadanía democrática nos muestra que sólo si somos capaces de abrirnos a los otros, ensanchar y ampliar nuestro horizonte colectivo del nosotros podremos generar una ciudadanía cosmopolita fundada en presupuestos universales. Una ciudadanía mundial claramente conectada a una urgente y necesaria Educación política y cívica. Una Educación para la ciudadanía seria y cabal debe desarrollar la capacidad de autonomía personal a través de valores superiores como igualdad, justicia, tolerancia, libertad. Evidentemente, este modelo radical de ciudadanía global ha recibido duras críticas, aunque muchos autores consideran viable la aparición de la ciudadanía trasnacional de alcance regional como la ciudadanía europea. El proceso de integración europea ha puesto de manifiesto su gran potencial de conformar una ciudadanía no definida según los esquemas tradicionales del Estado-nación moderno.

\section{III.5. Modelo de ciudadanía cosmopolita de Martha Nussbaum}

Martha Nussbaum defiende un cosmopolitismo global desde un posicionamiento moral y político fundado en la tradición kantiana y estoica en oposición a los distintos provincianismos, patriotismos localistas, nacionalismos y etnicidades localistas. Nuestra principal lealtad debe ser con el común de la humanidad, y los primeros principios de nuestro pensamiento práctico deben respetar el igual valor de todos los miembros de la comunidad. El cosmopolitismo ${ }^{35}$ es una

${ }^{35}$ Nussbaum Martha defiende o reivindica el legado cosmopolita de raíz estoicokantiana y neo-aristotélica para construir desde una ciudadanía mundial frente al 
postura controvertida, una tendencia de pensamiento político a la que se oponen quienes se resisten a su ideal de ciudadanía mundial en nombre de sensibilidades, sentimientos y apegos arraigados a la filiación grupal o a la tradición nacional.

En disputa con la visión izquierdista de Noam Chomsky que contempla como Estado Unidos está regido por una élite oligárquica cuyo objetivo es enriquecerse de la miseria de terceros países pobres, Rorty casi admite categóricamente el enorme peligro de su posición etnocentrismo radical patriótico: «desde esta perspectiva, no es que nuestro país esté en peligro de deslizarse hacia el fascismo, es que siempre ha sido cuasifascista [...] nosotros los deweynianos somos sentimentalmente patrióticos sobre los Estados Unidos, decididos de admitir el riesgo de que podría deslizarse hacia el fascismo, como orgullosos de su pasado y cautelosamente esperanzados con su futuro» 36

Richard Rorty contempla la sociedad occidental como aquella en que la tecnología y las instituciones democráticas pueden producir un incremento en la igualdad y un decrecimiento de sufrimiento. Y se siente orgulloso de los Estados Unidos, definiéndose como "sentimentalmente patriótico». Rorty defiende la necesidad de implicación emocional de los individuos en un proyecto colectivo nacional. «El orgullo nacional es para los países lo que la autoestima para los individuos: una condición necesaria para la autorrealización.» ${ }^{37}$

relativismo étnico-cultural, el nacionalismo excluyente o el patrioterismo chabacano y localista. Por tanto frente al planteamiento universalista rawlsiano el cosmopolitismo de Nussbaum arranca de la tradición estoico-ciceroniana, más cercano a la tradición y la cultura hispanoamericana, de forma tal que podemos considerar a esta autora como una de las principales figuras del neo-estoicismo norteamericano. Véase el excelente trabajo de Llano Alonso, Fernando H., El humanismo cosmopolita de Immanuel Kant, Instituto de Derecho Humanos «Bartolomé de las Casas, Dykinson, Madrid, 2002.

${ }^{36}$ RORTY, «Trostsky y las Orquídeas silvestres» en Pragmatismo y política, p. 43-44.

${ }^{37}$ No obstante, un exceso de orgullo nacional como el que ha vivido recientemente Estados Unidos puede llevarle a generar belicosidad, imperialismo e intervencionismo militar, al igual que demasiada autoestima puede generar arrogancia. Un patriotismo cívico-cultural como el que defiende Habermas puede ser pertinente para una nación. El "patriotismo constitucional» consiste en la lealtad a la Constitución y a la comunidad política democrática ajena a todo elemento o contaminación moral o étnica, si bien Habermas reconoce la inevitabilidad de tales impregnaciones. Habermas considera que el pluralismo de la sociedad actual es un pluralismo ético y étnico, que requiere de una neutralización de lo político si queremos conservar y mantener dicho pluralismo. De este modo, el patriotismo constitucional se opone al nacionalismo ${ }^{86}$ que toma el concepto de Nación como categoría política fundamental. La conciencia nacional se reduce a una dimensión ética y, por tanto, particular, cuyos rasgos comunes 
Estados Unidos constituye un proyecto abierto a innumerables perspectivas democráticas. Piensa que, pese a sus vicios y atrocidades pasadas y presentes, es un buen ejemplo del mejor tipo de sociedad inventada hasta el momento. En este tipo de declaraciones podemos apreciar claramente una excesiva dosis de complacencia etnocentrista, un mirarse el ombligo desde el orgullo de ser norteamericano.

Rorty en su libro Forjar nuestro país hace un alegato a favor del sentimiento de orgullo nacional. Este orgullo nacional «equivale al respeto de sí mismo del individuo: una condición necesaria para mejorar ${ }^{38}$. Una política liberal de mayoría progresista es imposible sin el patriotismo, normalmente la ausencia de patriotismo ${ }^{39}$ es la que ha dejado sin rumbo a la política de izquierdas.

Precisamente, la pensadora Martha Nussbaum critica fuertemente su exceso de patriotismo etnocentrista que no ayuda en nada hacia un cosmopolitismo político y democrático. «El patriotismo de Richard Rorty puede ser una forma de mantener unidos a los estadounidenses; pero el patriotismo está muy próximo al patrioterismo y tal como yo lo veo, me temo que en la argumentación de Rorty no hay ninguna propuesta que permita afrontar un peligro tan obvio como éste» ${ }^{40}$.

No obstante, la evolución de la ciudadanía democrática nos muestra que sólo si somos capaces de abrirnos a los otros, ensanchar y ampliar el horizonte colectivo del «nosotros» podremos generar una

como la lengua, la historia, la religión constituyen una peculiaridad que no debe ser decisiva ni determinante en la construcción de la Unión Europea. «La ciudadanía democrática -dice Habermas- no ha de menester quedar enraizada en la identidad nacional de un pueblo; (...) y con independencia de y, por encima de, la pluralidad de formas de vida culturales diversas exige la socialización de todos los ciudadanos en una cultura política común.» Cfr. Habermas, J., Facticidad y Validez, Madrid, Trotta, 1998, p. 629.

${ }^{8}$ RORTY, R., Forjar un país. El pensamiento de izquierdas en los Estados Unidos del siglo XX, Paidós, Barcelona, 1999.

${ }^{39}$ En este sentido, Martha Nussbaum trata de puntualizar que una mínimo de nacionalismo cívico solidario puede ser necesario para la cohesión grupal; pero la extralimitación de este sentimiento puede conducirnos hacia formas de discriminación, xenofobia y racismo.

${ }^{40}$ Nussbaum Martha C. (comp.) Los limites del patriotismo. Identidad, pertenencia y ciudadanía mundial. Paidós. Barcelona, 1999, p.26. Martha Nussbaum, basándose en el cosmopolitismo estoico de Marco Aurelio, Cicerón y Séneca así como en Emerson y Thoureau, es fuertemente autocrítica con el etnocentrismo excluyente creciente. Nussbaum señala la apabullante ignorancia de su propio país (USA) en cuanto se refiere a la mayor parte del resto del mundo y aboga por una educación cosmopolita para aprender más acerca de nosotros mismos. 
ciudadanía cosmopolita fundada en ciertos presupuestos universales, una ciudadanía que pueda combatir los excesos de los nacionalismos políticos. Una ciudadanía mundial claramente conectada con una educación político-cívica y el desarrollo de la cultura de los derechos humanos. Por tanto, una educación para la ciudadanía responsable debe desarrollar la capacidad de autonomía personal a través de valores superiores como igualdad, justicia, tolerancia, libertad.

«Así que la transformación americana es parte de una más amplia transformación del sistema mundial. Si el siglo XX fue el «siglo americano», el siglo XXI será el «siglo americanizado». El homólogo ideológico de esta transformación socioeconómica masiva es la piel descrita anteriormente, el ambiente comercial total que circunscribe todo un mundo mental. Un ciudadano ya no será un ciudadano en el sentido que esta palabra ha tenido siempre, y sea lo que sea, estará muy feliz de que se le ofrezca entretenimiento (o trascendencia) en lugar de valores.» ${ }^{41}$

El cosmopolitismo que propone Nussbaum consiste en el cultivo de la humanidad requiere o precisa de tres actitudes esenciales: $1^{\circ}$ ) Siguiendo el ideal socrático de «vida examinada», autoexamen crítico y cuestionamiento de las propias tradiciones y cultura. $2^{\circ}$ ) la capacidad de verse a sí mismos no solo como ciudadanos pertenecientes a una región o grupo, sino también como seres humanos vinculados a los demás seres humanos por lazos de reconocimiento y preocupación mutua. $3^{\circ}$ ) además de conocimiento factual se requiere «imaginación narrativa».

La posición política de Nussbaum gira en torno a la posibilidad de contribuir a través de la imaginación narrativa a desarrollar una imagen del kosmu polités (ciudadano del mundo), aduciendo que cada uno de nosotros habita en dos comunidades: la comunidad local en la que nacemos, y la comunidad de deliberación y aspiraciones humanas mayor. En este sentido, se constituye en una de las pensadoras contemporáneas que cree que las narraciones literarias son particularmente adecuadas para describir la experiencia moral y política de la ciudadanía. Las narraciones literarias conceden prioridad a lo

${ }^{41}$ Morris Berman, The twilight of American Culture, Norton\&Company, Inc, New York, (trad. Eduardo Rabasa, El Crepúsculo de la cultura Americana, Editorial Sexto Piso, México, 2007, p. 99). Los análisis políticos y culturales de Berman Morris son consecuentes a una actitud crítica de empobrecimiento y superficialidad que vive la cultura de los Estados Unidos de América.

${ }^{42}$ Normalmente, entendemos que la filosofía se ocupa de lo universal, mientras la literatura se centra en el detalle o particularidad. Nussbaum pretende rescatar la importancia que tienen las narrativas en la edificación moral y cívica individual y colectiva. 
particular sobre las reglas o principios generales ${ }^{42}$. Esta pensadora se pronuncia por un tipo de teoría moral alternativa y diferente a las doctrinas clásicas kantianas y utilitaristas. De este modo, acercarse a la literatura, en particular a la novela, resulta instructivo para esclarecer el tipo de cuestiones y preguntas que aquellas doctrinas excluyen. Ampliando la investigación ética a ciertas dimensiones de la experiencia real donde los sujetos se enfrentan a decisiones existenciales importantes.

«Por esta razón la literatura es tan importante para el ciudadano, como un medio de expansión de afinidades que la vida real no puede cultivar de modo suficiente. La promesa política de la literatura es que nos puede transportar, mientras seguimos siendo nosotros mismos, a la vida de otro, revelando las similitudes, pero también profundas diferencias ${ }^{43}$

A través de la literatura nos acercamos a todo lo que ha acontecido en el mundo o todo lo que puede acontecer. De este modo, las novelas pueden aproximarnos hacia una nueva filosofía moral y política, no como una disciplina académica, sino poniéndonos en contacto con lo más profundo de nuestra búsqueda en el terreno de la vida práctica, tanto respecto a nosotros mismos como en nuestra relación con los otros. La novela no sólo nos involucra en una participación amistosa de las aventuras de un personaje concreto, sino que nos amplia nuestro horizonte mental de lo que podría suceder en nuestras vidas.

Martha Nussbaum expresa: «Creo que Tagore estaba en lo cierto al observar que, en el fondo, el nacionalismo y el particularismo etnocéntrico no son ajenos uno del otro, sino que son afines; que el apoyar los sentimientos nacionalistas llega, en última instancia, a subvertir incluso los valores que mantienen unida a la nación, puesto que tales sentimientos sustituyen los valores universales y sustantivos de justicia y derecho por un pintoresco ídolo.» ${ }^{44}$

${ }^{43} \mathrm{Cfr}$. Nussbaum Martha, El cultivo de la humanidad. Una defensa clásica de la reforma de la educación liberal, Andrés Bello, Barcelona, 2003. p. 153.

${ }^{44}$ Cfr. Nussbaum Martha C. (comp.), Los limites del patriotismo. Identidad, pertenencia y ciudadanía mundial, Paidós, Barcelona, 1999, p.15 Martha Nussbaum, basándose en el cosmopolitismo estoico de Marco Aurelio, Cicerón y Séneca así como en Emerson y Thoureau, es fuertemente autocrítica con el etnocentrismo excluyente creciente. La profesora Nussbaum señala la apabullante ignorancia de su propio país (USA) en cuanto se refiere a la mayor parte del resto del mundo y aboga por una educación cosmopolita para aprender más acerca de nosotros mismos y superar, de este modo, un etnocentrismo radical y excluyente potencialmente peligroso. 
Cuando Diógenes, el cínico, respondió «Soy ciudadano del mundo» quiso decir, aparentemente, que se negaba a ser definido por sus orígenes locales y su pertenencia grupal, unos elementos que resultaban centrales para la imagen que de sí mismo tenía el hombre griego tradicional. La pensadora Nussbaum distingue dos versiones del cosmopolitismo ${ }^{45}$, una versión exigente y otra versión más flexible del ideal clásico del «ciudadano del mundo». La más exigente es el ideal de ciudadano cuya lealtad principal es para con los seres humanos de todo el mundo y cuyas lealtades nacionales, locales o grupales son secundarias. La versión moderada compatibiliza ambas lealtades tratando de armonizarlas. Estas dos versiones se han dado en el estoicismo romano. Nussbaum simpatiza con la versión más estricta; pero entiende que la versión más blanda e inclusiva es más acertada a nuestro mundo actual.

Los estoicos, posteriormente, desarrollaron su imagen del Kosmou polités aduciendo que cada uno de nosotros habita en dos comunidades: la comunidad local en la que nacemos, y la comunidad de deliberación y aspiraciones humanas que es «verdaderamente grande y verdaderamente común, en la que no miramos esta esquina ni aquella, sino que medimos las fronteras de nuestra nación por el sol» (Séneca, De otio) Ésta es la comunidad de la que, básicamente, emanan nuestras obligaciones morales, se trata del reconocimiento de la humanidad, de cifrar la lealtad.

Nussbaum concuerda con la idea e los estoicos de que la ciudadanía mundial no implica la creación de un Estado mundial, nos encontraríamos, por tanto, en el «reino de los fines» de Kant, es decir, dentro de un ideal regulativo más que una propuesta político-jurídica concreta, y en este sentido, la lealtad máxima es la debida a la comunidad moral de todos los seres humanos.

Analizando el problema de un orden político justo continuará la tarea de que la justicia es una tarea institucional, una tarea que implica no sólo al Estado-nación fundamentalmente, «pues la tarea de asegu-

${ }^{45}$ Vid. Agra Romero, María Xosé, «Ciudadanía: Fronteras, círculos y cosmopolitismo» en Anales de la Cátedra Francisco Suárez, Universidad de Granada, 36, 2002, pp. 9-28. Como señala María Xosé Agra Nussbaum se ocupa de mostrar la deuda de Kant con el cosmopolitismo estoico antiguo sobre todo con Cicerón.

${ }^{46}$ Vid. Nussbam, M., "Political Animals: Luck, Love and Dignity» art. cit. Nussbaum trata de articular una teoría de la justicia distributiva global que incide en cómo las naciones ricas del mundo están vinculadas a la historia de la dominación y explotación de los países pobres y que por ello son responsables de dicha situación; YounG, Iris Marion, La justicia y la política de la diferencia, trad. de S. Álvarez, Cátedra, Madrid, 2000. 
rar los bienes básicos de la vida para todos (libertades y oportunidades y bienes materiales) es la tarea de las instituciones políticas. ${ }^{46}$

Nussbaum se muestra cautelosa sobre la posibilidad de un gobierno mundial, aunque no descarta que la comunidad internacional debe presionar cada vez que más a las naciones que rehúsan reconocer los derechos humanos, creando así al menos un gobierno trasnacional tenue (thin); no obstante, muestra un cierto escepticismo al manifestar que no existe garantía alguna de que el gobierno mundial lo vaya a hacer mejor que los Estados-nación. La tarea es interdisciplinar, o sea, trabajar en los Estados-nación, a pesar de sus fallos, porque son «los lugares más manejables para presionar por la justicia».

«La perspectiva de Nussbaum, veíamos, va en la dirección de una teoría de la justicia global que está aún por articularse, pero no por ello se detiene. En este sentido su concepción se nuclear en torno a la necesidad de abordar los graves y urgentes problemas de pobreza en el mundo, de desarrollo y, muy en especial, la situación de las mujeres pobres en los países pobres. Abogando por un feminismo internacional.» ${ }^{47}$

Benjamin Barber critica este cosmopolitismo porque piensa que el patriotismo tiene sus patologías, pero el cosmopolitismo también como puede ser las distintas formas de imperialismo. En oposición al cosmopolistismo de Nussbaum fundado en el compromiso de una persona con la comunidad de seres humanos, Barber opone el compromiso con el granjero, el minero, el marinero, el carpintero. Para Barber nuestro mundo ha sido desencantado por el mercado y la comunidad local ha sido sustituida, en su mayor parte, por el Estado y la burocracia. Por tanto, "[...] Lo que necesitamos son formas de comunidad local y patriotismo cívico saludable y democráticas, y no un universalismo abstracto ni un amasijo de relaciones contractuales. ${ }^{48}$ Barber defiende un patriotismo cívico que trate de evitar la exclusión, pero que satisfaga la necesidad de identidad provinciana y sentimiento de pertenencia en oposición a las versiones patológicas

${ }^{47}$ Vid. Nussbaum, M., Sex and Social Justice, Oxford University Press, Oxford, 1999 y Women and Human Development, Cambridge University Press, Cambridge, 2000; Young, Iris Marion, La justicia y la política de la diferencia, trad. de S. Álvarez, Cátedra, Madrid, 2000.

${ }^{48}$ BARBER, Benjamin, «Fe constitucional» en Nussbaum Martha C. (comp.), Los limites del patriotismo. Identidad, pertenencia y ciudadanía mundial, Paidós, Barcelona, 1999 , p. 50 
de genocidio que se han producido en Yugoslavia, Rumania, Ruanda, Nigeria, Ucrania, Afganistán.

«El patriotismo patológico sólo se puede curar mediante un patriotismo sano, así como el patrioterismo se cura solamente con una pacífica fe constitucional; el nacionalismodestructivo sólo mediante el liberalismo nacional y la etnicidad separatista y excluyente con la etnicidad multicultural. Si las tribus de la comunidad tradicional son peligrosas, entonces debemos encontrar formas de comunidades igualitarias, democráticas y voluntaristas en las que este peligro deje de existir.» ${ }^{49}$

Benjamin Barber propone un nacionalismo cívico en oposición a los nacionalismos folklóricos y sentimentales que no implican grados de compromiso en la defensa de los derechos fundamentales o nacionalismos fundamentalistas excluyentes que atentan contra los mismos derechos fundamentales.

\section{EL FUTURO DE LA CIUDADANÍA COSMOPOLITA ANTE LA CRISIS DEL ESTADO-NACIÓN}

Considero que debemos profundizar hacia una democracia republicana y comunitaria donde la participación política no se agote o se reduzca a la mera emisión del voto (democracia estrictamente electoral). Una democracia republicana no se reduce a un sistema numérico de mayorías y minorías, ni la democracia consiste en la tiranía de la mayoría sobre la minoría, sino la posibilidad de expresión del pluralismo político de una sociedad. En este aspecto, nos urge convertir nuestras democracias formales vacías del voto a democracias participativas e integradoras del pluralismo social. Esto implica un política democrática radical que pueda integrar y hacer partícipes a los ciudadanos desde un modelo de democracia deliberativa, sólo así alcanzaremos y desarrollaremos una responsabilidad colectiva hacia los asuntos públicos (res pública). La democracia al igual que la ciudadanía sigue siendo un proyecto moderno de vocación fuertemente universal que puede superar a los Estados, las fronteras y, por tanto, no puede ser coartada o impedida por éstos. Los derechos humanos por su fuerte dimensión deontológica conectada a presupuestos iusnaturalistas de inequívoco signo cosmopolita son los que asumen esa dimensión de indudable e ineludible vocación universalista.

${ }^{49}$ Ibid., p. 51.

(C) UNED. Revista de Derecho UNED, núm. 8, 2011 
En resumen, la historia de la ciudadanía desde su nacimiento nos muestra la posibilidad de una ciudadanía que no sea excluyente, limitada o reducida. Sólo si somos capaces de abrirnos a los otros, ampliar y ensanchar el horizonte del nosotros podremos generar una nueva ciudadanía ética y coherente con sus propios presupuestos normativos. Considero que es fundamental reactivar el concepto de ciudadanía universal y cosmopolita claramente conectado e imbricado a una cultura sólida de derechos humanos y un proceso de educación cívico-política, si queremos edificar, renovar, fortalecer un auténtico modelo de democracia constitucional y deliberativa. Una educación para la ciudadanía debe desarrollar la capacidad de autogobierno, autolegislación, autocontrol de las vidas personales de los ciudadanos, en definitiva, se trata de continuar y desarrollar el programa Ilustrado moderno, corrigiendo todos sus posibles errores y potenciando sus virtualidades para generar una nueva ciudadanía activa y democrática como realidad fáctica y tangible. La escuela sigue siendo la institución formativa por excelencia que mejor forma y modela a los ciudadanos proporcionándoles los medios concretos adecuados para participar realmente en la vida pública; es la que asegura el carácter democrático de lo político, por eso, tenemos que integrar esta educación cívica en el currículum formativo de la Educación media y superior.

La irrupción de la sociedad global y la mundialización de las relaciones políticas abren nuevas perspectivas a los distintos individuos, grupos, movimientos sociales, políticos y sociedades nacionales. La ciudadanía como soberanía o autodeterminación político-jurídica implica autoconciencia y deliberación pública, sin embargo, en este aspecto debemos ser conscientes y realistas de que dicha autonomía personal es todavía muy precaria, pobre y limitada en nuestras sociedades de masas, de lo que se trataría entonces es de desarrollarla, fortalecerla y ampliarla. Según Richard Falk ante el contexto de globalización que pone en peligro la soberanía de muchos Estados «[...] la viabilidad ética del patriotismo depende de que el Estado disponga del suficiente espacio político como para permitir el surgimiento y mantenimiento de dicho Estado humano, y para hacer que la viabilidad e importancia del proyecto estimulen la participación ciudadana. ${ }^{50}$

${ }^{50}$ FALK, Richard, "Una revisión del cosmopolitismo» en Nussbaum Martha C. (comp.), Los límites del patriotismo. Identidad, pertenencia y ciudadanía mundial, Paidós, Barcelona, 1999, p. 67. 
Esta concepción, sin duda, ha de ser respaldada por un modelo de ciudadanía más amplio, dinámico y profundo de los problemas cruciales por los que atraviesa América Latina como continente en un proceso continuo de crecimiento y desarrollo: el problema de las desigualdades socio-económicas, la profundización de los derechos fundamentales no sólo en el sentido individual, sino también grupal y colectivos (étnico, nacional, religioso, de género,...). Sólo desde este segundo modelo de ciudadanía compleja y diferencial (multicultural) $)^{51}$ podremos hacer frente y resolver los enormes problemas de justicia planteados en el momento presente desde criterios más distributivos, solidarios y equitativos.

\section{BIBLIOGRAFÍA}

Agra Romero, María Xosé, «Ciudadanía: Fronteras, círculos y cosmopolitismo» en Anales de la Cátedra Francisco Suárez, Universidad de Granada, 36, 2002, pp. 9-28.

Aguilera Portales, Rafael Enrique, Pragmatismo político: la democracia sin fundamentos en Richard Rorty (Análisis y revisión crítica de su Teoría Política), Editorial Fontamara, México, 2011.

- Teoría Política del Estado Constitucional, México, Porrúa, 2011.

- La ciudadanía y la participación política en el Estado democrático, México, Porrúa, 2010.

- Teoría política y jurídica contemporánea (Problemas actuales), México, Editorial Porrúa, 2008.

mica, México, Editorial Porrúa, 2008.

- Nuevas perspectivas y panoramas de la democracia en el Estado Constitucional, México, Porrúa, 2009.

Aguilera Portales, Rafael Enrique y Escámez Navas, Sebastián (ed.), Pensamiento Político Contemporáneo: una panorá- «La encrucijada de una ciudadanía constitucional europea a través del pen-

${ }^{51}$ Vid. Kymlicka, W., Ciudadanía multicultural, Una teoría liberal de los derechos de las minorías, Paidós, Barcelona, 2000. Como dice SAMI NAîR: «esta globalización engendra la mutación de pertenencias, la desregulación de la identidades nacionales, la ausencia de un paradigma de referencia colectiva. De ahí el repliegue sobre los marcadores primarios: la identidad personal, la referencia confesional, la pertenencia étnica, la identidad lingüística diferenciada, etc.» $C f r$. SAMI NAÎR, «Los inmigrantes y el Islam europeo», Claves de la Razón práctica, n.105, septiembre, 2000, p. 8. 
samiento federalista» en Torres Estrada, Pedro (ed.) La Reforma del Estado, Editorial Porrúa, México, 2007.

Arias Maldonado, Manuel, Sueño y mentira del ecologismo. Naturaleza, sociedad, democracia, Madrid: Siglo XXI, 2008.

- Manuel, Ciudadanía y conciencia medioambiental en España (en colaboración con Ángel Valencia Sáiz y Rafael Vázquez García), Centro de Investigaciones Sociológicas, Madrid, 2010.

Barber, B., Strong Democracy. Participatory Politics for a New Age, Univ. Of California Press, 1984.

BECK, U., ¿Qué es la globalización?, Barcelona: Paidós, 1998.

Berlin, I., El fuste torcido de la humanidad, Barcelona, Península, 1992.

Carbonell, M.: Neoconstitucionalismos, Madrid, Trotta, 2003.

Del Real Alcalá, Alberto, «Del Estado-nación de Derecho al Estado de Derecho postnacional. Análisis de la tesis de L. Ferrajoli sobre la desnacionalización de la teoría de los derechos», en Derechos y Libertades, n. ${ }^{\circ}$ 13, Instituto de Derechos Humanos Bartolomé de las Casas y Boletín Oficial del Estado, Madrid, Enero-Diciembre 2004, pp. 361-381.

— «Estado cosmopolita y Estado nacional. Kant vs. Meinecke», en Castro Alfonso; Contreras, F.J., Llano, Fernando; Panea, José M. (eds): A propósito de Kant. Estudios conmemorativos en el bicentenario de su muerte, 2. ${ }^{\mathrm{a}}$ edición revisada y ampliada, prólogo de Antonio Enrique Pérez Luño, epílogo de Pablo Badillo O’Farell, Editorial Grupo Nacional de Editores, Sevilla, 2004, pp. 307-340.

— «Sobre la indeterminación del Derecho y la Ley constitucional. El caso del término 'nacionalidades' como concepto jurídico indeterminado", en Derechos y Libertades, n. ${ }^{\circ} 11$, Instituto de Derechos Humanos Bartolomé de las Casas y Boletín Oficial del Estado, Madrid, Enero-Diciembre 2002, pp. 223-250.

Del Aguila, Rafael, La senda del mal: política y razón de Estado, MADRID, TAURUS, 2000.

De Lucas Martí, J., La inmigración, por Derecho, Editorial Tirant lo Blanch, Valencia, 2004.

De Miguel, I. «¿Hacia el fin del Estado-Nación?, En Cuadernos de Electrónicos de Filosofía del Derecho, Núm. 5, 2002. 
De Asís, Rafael, Las paradojas de los derechos fundamentales como límites al poder, Debate, Madrid, 1992 De Asís, R., Concepto y fundamento de los derechos: Una aproximación dualista, Cuadernos Bartolomé de las Casas, 17, Dykinson, Madrid, 2001.

DE LUCAS, J., El concepto de solidaridad, Fontamara, México,1993.

De Lucas Martín, J. ¿Qué quiere decir tener derecho a la cultura? en Abramovich, V., AÑon, M. J., CourTIS, Ch.(comp.) Derechos sociales, México, Fontamara, 2003.

Deleeck, Herman. "L'effet Mathieu » en : Droit Social. Paris. Num. 11, 1979.

Díaz, Elías. «Estado de Derecho y Sociedad Democrática». Cuadernos para el diálogo. Madrid. 1969.

DUVERGER, Maurice. «Institutions politiques et droit constitutionnel». Presses universitaires de France. Paris. 1963.

EscÁmez Navas, Sebastián, «El Estado de la virtud. Sobre la noción de tolerancia en el liberalismo político de John Rawls», Isegoria, núm. 31, diciembre 2004, pp. 47-78.

— „La idea liberal de tolerancia en las democracias contemporáneas», Política y Cultura, Universidad Autónoma Metropolitana (Unidad Xochimilco), México, núm. 21, 2004.

Elster, J., Making sense of Marx, Cambridge University Press, Cambridge, 1985.

FERnÁNDEZ, E., Dignidad humana y ciudadanía cosmopolita, Cuadernos Bartolomé de las Casas, 21, Dykinson, Madrid, 2001.

FernandeZ-Miranda, Alfonso. «El Estado Social». Revista Española de Derecho Constitucional, Madrid, No 69, año 23, Sept/Dic. 2003.

FerRAJoli, Luigui. «Derechos y garantías: La Ley del más débil». Madrid. Ed. Trotta. 1999.

García Álvarez, M. B., Las Constituciones de los países socialistas, Ed. Celarayn, León, 1980.

Galindo Camacho, Miguel. "La Constitución mexicana de 1917 como modelo de la evolución del Derecho Constitucional de los países iberoamericanos» EN: Memorias del III Congreso Iberoamericano de Derecho Constitucional T.I. México. Instituto de investigaciones jurídicas. UNAM.1987. 
Garcia Pelayo, Manuel. «Obras completas» Tomo II. Madrid. Centro de Estudios Constitucionales, 1991.

GaRrido Falla y otros. "Comentarios a la constitución» Civitas. Madrid. 1985.

GonzÁLEz Moreno, B., El Estado social, Naturaleza Jurídica y estructura de los derechos sociales, Madrid, Civitas, 2002.

GidDENS, Anthony. «La tercera vía: La renovación de la Social Democracia». Taurus. Buenos Aires. 1999.

Gómez GARcía, Juan Antonio: «La estructura filosófica de la postmodernidad político-jurídica. Una hermenéutica estructural de la teoría sistémica de Niklas Luhmann», en Anales de la Cátedra Francisco Suárez, Universidad de Granada, núm. 43, 2009.

- Valores jurídicos y derechos humanos en el Cine. Madrid: Universidad Nacional de Educación a Distancia, 2002.

— „La dimensión social de la vida humana», pp. 41-50; »Derecho, Moral y Usos Sociales», pp. 85-100 y »El nacimiento de la norma jurídica», pp. 119-129, en VV.AA.: Teoría del Derecho. Madrid: Universidad Nacional de Educación a Distancia - Unidades Didácticas, 2003.

— „El Estado del bienestar en la era de la globalización», en VV.AA.: La globalización y la crisis de los derechos. Madrid: Universidad Nacional de Educación a Distancia, 2005, pp. 77-92.

GonzáLez Moreno, Beatriz. «El Estado social: Naturaleza jurídica y estructura de los derechos sociales» Ed. Civitas. 2002. Madrid.

Gutiérrez Sastre, Martha, La participación en los servicios públicos de bienestar, Madrid, 2005, Consejo Económico y Social, p. 29.

Habermas, J., Crisis de legitimación del capitalismo tardío, Madrid, Cátedra, 1989.

- La reconstrucción del materialismo histórico, (trad. Jaime Nicolás Muñiz y Ramón García), Madrid, Taurus, 1981.

- (1994), Fäktitizität und Geltung. Francfort, Suhrkamp (ed. ampliada de la 1a de 1992).

— «La crisis del Estado de bienestar y el agotamiento de las energía utópicas» en Ensayos políticos, Madrid, Península, 1999.

HÄBERLE, P. El Estado constitucional, (trad. Héctor Fix-Fierro), Universidad Nacional Autónoma de México, México, 2001, Hauriou, 
André. «Derecho constitucional e instituciones políticas» Barcelona. Ed. Ariel. 1971.

Hannah, Arendt: La condición humana, Barcelona, Paidós, 1998.

Heller, Hermann, Escritos Políticos, Alianza Universidad, Madrid, 1985.

Kymlicka, W., Ciudadanía multicultural, Una teoría liberal de los derechos de las minorías, Paidós, Barcelona, 2000.

LAPORTA, F., «Sobre el uso del término libertad en el lenguaje político», en Sistema, núm.52, 1983.

Lucas Verdú, P., Estado liberal de Derecho y Estado social de Derecho, Salamanca, Acta Salmanticensia, 1955.

Marschall, Th. H. Citizenship and Social Class, 1950, (trad. cast. Marschall, Th. H, y Bottomore, T. Ciudadanía y Clase social, (trad. Pepa Linares), Alianza Editorial, Madrid, 1998.

NEGRI, A.,El poder constituyente: ensayo sobre las alternativas de la modernidad, Madrid, Ed. Libertarias.

Navarro, V., Schmitt, J., Astudillo, J. , «La importancia de la política en la supuesta globalización» en Sistema, n. 171.

Olivas CABANILLAS, Enrique, «El hombre natural y la prudencia política (anotaciones sobre la modernidad de B. de Spinoza y el proceso político» en Revista de estudios políticos, $\mathrm{N}^{\circ}$ 95, 1997, pp. 295-306.

— «Globalización y derecho: una aproximación desde Europa y América Latina» En Dilex, 2007.

Peces-Barba, G. «La universalidad de los derechos humanos» en Nieto Navia, R. (ed,) La Corte y El Sistema Interamericano de Derechos Humanos, Corte IDH Ed., San José, 1994, pp. 399-421.

- (1999), Derechos sociales y positivismo jurídico, Cuadernos Bartolomé de las Casas, n. 11, Dykinson, Madrid.

Perez Luño Antonio, Derechos humanos, Estado de Derecho y Constitución, 3ra.edic. Madrid. 1990.

- A. Los derechos fundamentales, 5ta. Edic., Tecnos, Madrid 1993.

Rawls, J., A Theory of Justice, Oxford, 1972 (Ed. cast. Teoría de la Justicia, trad. De M.d. González, México, FCE, 1993.)

SAHUI, Alejandro (coord.), Gobernanza y sociedad civil: retos democráticos, México, Ediciones Coyoacán, 2009. 
SAHUI, Alejandro, Jürgen Habermas: esfera pública, autonomía compleja y ciudadanía en AguiLera Portales, Rafael Enrique y EscÁMEZ Navas, Sebastián (ed.), Pensamiento Político Contemporáneo: una panorámica, México, Editorial Porrúa, 2008.

SANZ BuRgos, Raúl, «¿Ofrecen las transformaciones globales oportunidades a la democratización?» en AguiLERA PorTales, Rafael Enrique (coord.), La democracia en el Estado Constitucional, México, Porrúa, 2009.

Schмiтt, Carl, Teoría de la Constitución (trad. Cast. F. Ayala, del original alemán Verfassungslehre, München/Leipzig, 1928), $1^{\circ} \mathrm{ed}$., Alianza Universidad, 1982.

Titmus, Richard. Essays of the Welfare State. Londres. George Allen and Unwim. 1963.

TAYloR, Charles: Argumentos Filosóficos, Paidós, Barcelona, 2000.

VAlencia SÁiz, Ángel, y Fernández-Llebrez GonzÁlez, Fernando, coord., La teoría política frente a los problemas del siglo XXI, Universidad de Granada, Granada, 2004.

VALENCIA, Ángel, «Andrew Dobson y la teoría política verde» en AGUILERA Portales, Rafael Enrique y Escámez Navas, Sebastián (ed.), Pensamiento Político Contemporáneo: una panorámica, México, Editorial Porrúa, 2008.

VAllesíñ, F., El futuro de la política, Taurus, Madrid, 2000. 